\title{
An alternative approach using integrated gamma-ray and geochemical data to estimate the inputs to subduction zones from ODP Leg 185, Site 801
}

S. Révillon

Department of Geology, University of Leicester, University Road, Leicester LE1 7RH, United Kingdom

Now at Southampton Oceanography Centre, School of Ocean and Earth Science, Waterfront Campus, European Way, Southampton SO14 3ZH, United Kingdom.(sxr@soc.soton.ac.uk; sido_revillon@yahoo.com)

S. R. Barr, T. S. Brewer, and P. K. Harvey

Borehole Research Group, University of Leicester, University Road, Leicester LE1 7RH, United Kingdom

(srb7@le.ac.uk; tsb5@le.ac.uk; pkb@le.ac.uk)

\section{J. Tarney}

Department of Geology, University of Leicester, University Road, Leicester LE1 7RH, United Kingdom (art@le.ac.uk)

[1] The goal of the subduction factory project is to obtain a better understanding of processes occurring at convergent margins and performs mass balance calculations for tracer elements. As part of this project, a major objective of ODP Leg 185 is to determine the chemical composition of the inputs to the West Pacific Subduction Factory for use in calculations of elemental mass balance across the subduction zone. To understand such elemental budgets, it is critical to know the lithological diversity and chemical characteristics of the down going oceanic plate. Hole $801 \mathrm{C}$, located ocean-ward of the Mariana island arc system, is the most complete section of old oceanic crust sampled to date but, core recovery in basement holes is often poor (e.g., $<30 \%$ ) resulting in a bias such that the less altered material is preferentially recovered. Integration of drilled cores and downhole wire line logging data was performed to reconstruct a complete section of the drilled basement. Furthermore we integrate gamma ray logging data with the geochemical analyses of recovered cores to estimate the average composition, in terms of potassium and uranium, of the volcanic section in Hole 801C. We used FMS (Formation MicroScanner) images to relocate the samples with respect to the logging depth and to directly compare the logging data and the geochemical data. We demonstrate that the logging tool is well calibrated for $\mathrm{K}$ and $\mathrm{U}$ in the basement and that differences observed between $\mathrm{K}_{2} \mathrm{O}$ and $\mathrm{U}$ contents measured by the tool and by geochemistry are strongly dependent on the nature of the samples. The average $\mathrm{K}_{2} \mathrm{O}$ concentration of Hole $801 \mathrm{C}$ basement section is $0.34 \mathrm{wt} . \%$ using core-derived proportions, $0.51 \mathrm{wt} . \%$ using log-derived proportions and $0.47 \mathrm{wt} . \%$ using the gamma ray data. In the same manner the average $\mathrm{U}$ concentrations are respectively $0.34 \mathrm{ppm}, 0.39 \mathrm{ppm}$ and $0.42-0.5 \mathrm{ppm}$. This implies that $\mathrm{K}$ and $\mathrm{U}$ budgets recycled in the Mariana subduction zone are $20-50 \%$ higher than previously reported. These results demonstrate that a careful core-log-geochemical integration is essential to accurately estimate the composition of a drilled section and in order to better constraint chemical fluxes into subduction zones.

Components: 10,198 words, 10 figures, 3 tables.

Keywords: Subduction Factory; ODP Leg 185; core-log integration; geochemistry; K; U budgets.

Index Terms: 1030 Geochemistry: Geochemical cycles (0330); 0930 Exploration Geophysics: Oceanic structures; 0932 Exploration Geophysics: Radioactivity methods. 
Received 12 March 2002; Revised 30 August 2002; Accepted 16 September 2002; Published 31 December 2002.

Révillon, S., S. R. Barr, T. S. Brewer, P. K. Harvey, and J. Tarney, An alternative approach using integrated gamma-ray and geochemical data to estimate the inputs to subduction zones from ODP Leg 185, Site 801, Geochem. Geophys. Geosyst., 3(12), 8902, doi:10.1029/2002GC000344, 2002.

Theme: Oceanic Inputs to the Subduction Factory

Guest Editors: Terry Plank and John Ludden

\section{Introduction}

[2] The Subduction Factory project aims to perform mass balance calculations for tracer elements, and measures the chemical fractionation occurring between elements by comparing the inputs, at trenches, and the outputs at the arcs, of subduction zones [Morris et al., 1998; Plank et al., 1998]. This goal requires reliable, quantitative and representative, input and output data in terms of both compositions and volumes.

[3] Ancient Pacific crust (Jurassic, [Pringle, 1992; Bartolini and Larson, 2001]) about to be subducted at the Mariana-Izu-Bonin subduction zone was drilled during ODP Legs 129 and 185 to sample the material soon to be subducted. Several sites (including 801 and 1149) were drilled and logged seaward of the Mariana and Izu-Bonin trench systems (Figure 1). The processes operating within the arc systems and the physical attributes of the subduction zones have been extensively characterized such that the subduction geometry [Taylor, 1992; Van der Hilst and Senon, 1993; Fryer et al., 1999], the convergence vectors, the thickness of upper plate and slab temperature, are all fairly well defined [Van der Hilst and Senon, 1993; Fouch and Fischer, 1996; Suyehiro et al., 1996]. Complete sediment subduction occurs at both the Mariana and Izu-Bonin trenches [Taylor, 1992]. The upper plate in both cases is oceanic, so the effects of crustal contamination on arc magmas are minimal. However, there are variations in the geochemical signal of the arc volcanoes both along strike and across the Mariana-Izu-Bonin volcanic arc system [Stern et al., 1990; Tatsumi et al., 1992; Elliot et al., 1997; Peate and Pearce,
1998; Ishikawa and Tera, 1999]. These variations may be attributed to a number of factors, such as the nature of the inputs to the subduction zone, the processes operating within the subduction zone, the physical attributes of the subduction zone, or a combination of any or all of these. There are a wide range of inputs to the system including sediments, seamounts and altered oceanic crust. Key tracer elements for mass balance calculations, such as Th, Rare Earth Element (REE), Ba or Be are stored within sediments deposited on the subducting plate but the principal reservoir for other elements, particularly $\mathrm{K}, \mathrm{B}, \mathrm{U}, \mathrm{CO}_{2}$ and $\mathrm{H}_{2} \mathrm{O}$, is the uppermost, oxidised portion of the volcanic ocean basement. The input of these elements to an arc system varies as a function of both the sediment composition [Plank and Langmuir, 1998] and the structure of the volcanic basement [Staudigel et al., 1995, 1996; Alt et al., 1998; Alt and Teagle, 1999]. It is therefore critical to obtain accurate estimates of the composition of the subducted oceanic crust.

[4] A major problem arising during drilling in ocean crust is that complete core recovery is rare due to the fractured nature of the rocks and large contrasts in the competency of the material drilled. It is therefore difficult to determine a reliable and representative average composition for the oceanic crust, particularly considering that the altered or brecciated portions, containing most of the mobile elements, are usually more poorly recovered [Brewer et al., 1998; Lovell et al., 1998; Brewer et al., 1999]. During ODP Legs 129 and 185, $474 \mathrm{~m}$ of oceanic crust was drilled at Hole $801 \mathrm{C}$, thus providing a significant penetration of the upper oceanic basement, but only $47 \%$ of the basement cored was recovered (Figure 2). 


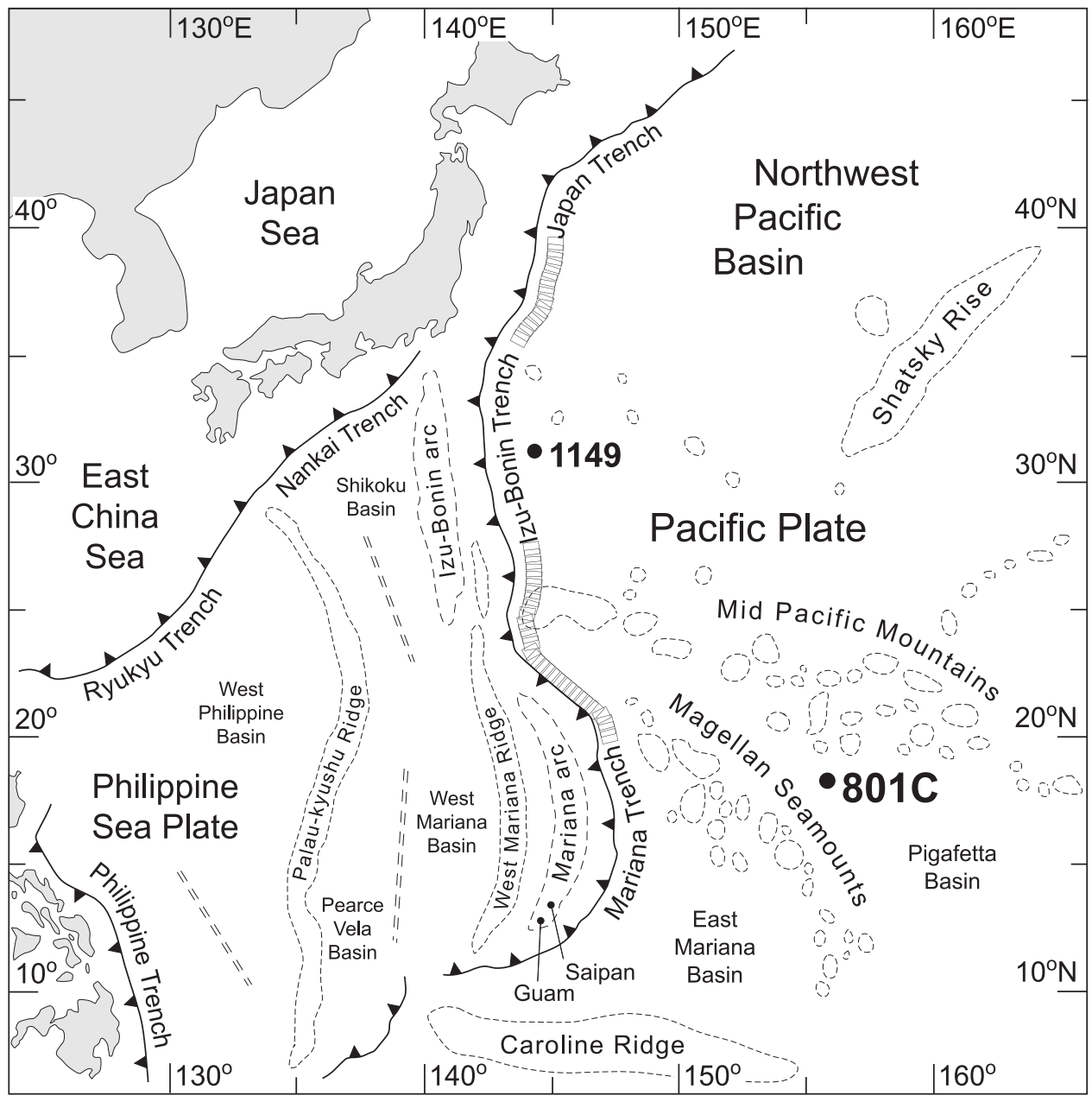

Figure 1. Location map of ODP Leg 185 Sites 801 and 1149 in relation to the Marianna arc system.

[5] To estimate the overall composition of the oceanic crust, one approach utilises a physical mixture of different rock types, with sample powders combined to produce a "composite" sample [Staudigel et al., 1995, 1996; Plank et al., 2000]. Small amounts of material from a large number of samples are combined in one or several composite samples. However, even if the recovered cores are quantitatively described, it is difficult to combine each rock type in the correct proportions because the cores are generally not fully representative of the drilled basement.

[6] In this paper, we present an alternative approach, in which geochemical analyses and logging data, specifically the gamma-ray data are integrated to provide a continuous record of geochemical variations. We also demonstrate that gamma ray data, yielded by wire line logging, can be used as a proxy for $\mathrm{K}_{2} \mathrm{O}$ and $\mathrm{U}$ contents downhole.

\section{Geological Background, and Results From Core-Log Integration}

[7] Hole $801 \mathrm{C}$ is located within the Pigafetta Basin in West Pacific oceanic crust (Figure 1). It lies within the Jurassic magnetic quiet zone and penetrates the oldest oceanic crust drilled to date, at $166 \pm$ 4.5 Ma from radiometric dating [Pringle, 1992] or 170-175 Ma from biostratigraphic studies [Bartolini and Larson, 2001]. This crust formed at fast spreading rates [Plank et al., 2000]. Hole $801 \mathrm{C}$ was first drilled during ODP Leg 129, to a total depth of 594 meters below seafloor (mbsf) [Lancelot et al., 1990]. The entire sedimentary pile was drilled dur- 


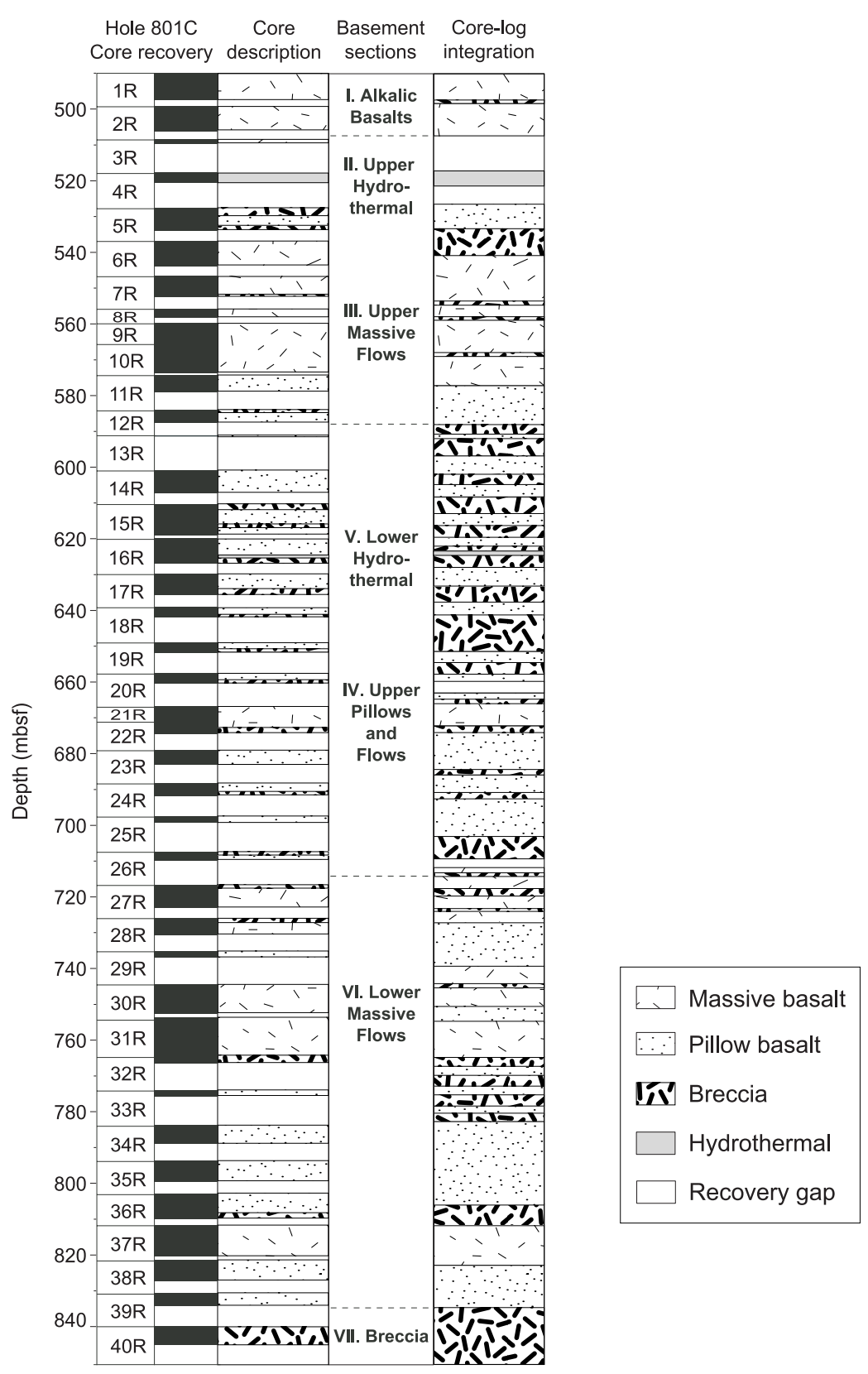

Figure 2. Results of the core-log integration study. Shown from left to right are the recovery during leg 185 , the lithology column established from the cores, the basement section units and the lithology column extracted from the downhole logging data. Modified from Barr et al. [2002].

ing Leg 129 and approximately $130 \mathrm{~m}$ into the basement. During ODP Leg 185, the hole was reentered and deepened to 935.4 mbsf [Plank et al., 2000]. Site 801C was first logged during ODP Leg 144 [Shipboard Scientific Party, 1993; Haggerty et al., 1995] and re-logged during Leg 185 [Plank et al., 2000]. The basement stratigraphy of the logged interval in Hole 801C (Figure 2) comprises seven major eruptive sequences (see also Plank et al.
[2000] and Barr et al. [2002] for a more detailed description). The uppermost section consists of alkali basalts and extends from 490 to $510 \mathrm{mbsf}$ [Floyd and Castillo, 1992]. A sequence of tholeiitic upper massive flows, from 530 to $590 \mathrm{mbsf}$, is separated from the alkali basalts by a first hydrothermal zone at 510-530 mbsf. The next section consists of pillows and flow units, down to $715 \mathrm{mbsf}$ and a second hydrothermal zone occurs within this 
sequence at around $625 \mathrm{mbsf}$. The lower sequence of massive flows extends down to $835 \mathrm{mbsf}$ and is followed by a thick breccia unit (Figure 2).

[8] Wire line logging data, including physical properties measurements such as velocity, resistivity, porosity, density, gamma ray and FMS (Formation MicroScanner) images were used to reconstruct a complete basement section [Barr et al., 2002]. The rock types were first identified within recovered cored intervals and criteria were defined to extrapolate to sections of poor recovery. This integration of core and logging data has allowed us to establish a continuous downhole stratigraphy. Results of this integration are summarized in Figure 2 (and presented in detail in Barr et al. [2002]). The results highlight a significant difference in the proportions of pillow basalts and breccia, with twice the amount of pillow material (32.7\% compared with $15.3 \%$ present or $27.8 \%$ if recovered core proportions are expanded to $100 \%$ recovery), and six times more breccia (31.3\% compared with $4.5 \%$ present or $8.1 \%$ for the expanded value) than is indicated by considering the recovered core description alone. The proportion of massive basalt is approximately the same for the two approaches (27.4\% compared with $33.4 \%$ present) but highly overestimated if an expanded approach is adopted (60.6\%) (see also Barr et al. [2002] for a complete discussion). Similarly the proportions of interpillow sediments and hydrothermal material are almost equal, although it should be noted that the proportion of interpillow sediment reported after core-log integration is likely an underestimate, because some pillow or breccia units contained sediments that were not distinguished as separate logging units [Barr et al., 2002].

\section{Analytical Techniques}

\subsection{Logging Data}

[9] The natural radioactivity of the formation was measured using the Hostile Environment Natural Gamma Ray Sonde (HNGS) and the Natural Gamma Ray Tool (NGT). The HNGS and NGT record the radioactivity of a formation, which is due to the presence of the naturally occurring radioactive isotopes of $\mathrm{K}, \mathrm{U}$ and Th [Rider, 1996]. Conventional tools consist of a scintillation counter, normally a sodium iodide crystal, and a photomultiplier. Measured energy values can be used to identify the gamma radiations in several energy windows, which in turn can be used to separate the energy peaks of the individual radioactive elements [Rider, 1996]. Although the data for the different tool runs are all in good agreement, we have used the data from the main HNGS run from Leg 185 for this study. The HNGS makes similar measurements to the NGT but the HNGS has a greater sensitivity and is capable of making measurements in difficult hole conditions. The HNGS employs bismuth germanate scintillation detectors, which are more sensitive than the sodium iodide crystal used by the NGT and afford better nuclear decay statistics. The HNGS measures total gamma and uses 5-window spectroscopy to resolve the detected spectrum into $\mathrm{K}, \mathrm{U}$ and Th concentrations. The high-energy part of the spectrum is divided into three energy windows, each covering a characteristic peak of the three radioactivity series. The concentration of each component is determined from the count rates in each window. Because the high-energy region contains only $10 \%$ of the total spectrum count rates, the measurements are subject to large statistical variations, even using a low logging speed. The results are considerably improved by including the contribution from the low-energy part of the spectrum. Filtering techniques are used to further reduce the statistical noise by comparing and averaging counts at a certain-depth with counts sampled just before and just after. The final outputs are the total gamma ray, a uranium-free gamma ray measurement, and the concentrations of potassium, thorium, and uranium. A real time borehole size correction is also applied to the data during acquisition. The concentrations of radioactive elements are generally very low in fresh Mid-Ocean Ridge Basalts (MORB), but the gamma ray log can be a good indicator of the extent of alteration degree as it is sensitive to the presence of potassium-bearing minerals and secondary minerals have relatively high K contents [Harvey et al., 1998; Borehole Research Group, 2000].

[10] The sampling interval of the tool is $15 \mathrm{~cm}$ and its vertical resolution is estimated to $46 \mathrm{~cm}$ [Rider, 1996; Plank et al., 2000]. The radius of investiga- 
tion of the tool depends on several factors such as the hole size, the mud density and the energy of the gamma rays (a higher energy gamma ray can reach the detector from deeper in the formation) [Borehole Research Group, 2000]. The concentrations measured by the tool are representative of a specific volume and the signal of a small feature, a vein for example, is "diluted" by the signal of the surrounding basalt. $\mathrm{K}_{2} \mathrm{O}, \mathrm{U}$ and Th contents reported by the tool in a specific interval can therefore be different than those measured on specific samples, which usually sample a smaller volume.

[11] Together with gamma-ray data we used FMS images to help relocating the samples and to identify the un-recovered material. The FMS is a microelectrical imaging device that responds to relative differences in conductivity in the borehole wall. The images can be regarded as oriented resistivity maps of textural variations in the borehole walls, reflecting resistivity contrasts and porosity and grain size variations between the various lithologies. Dark and light colors indicate low and high micro-resistivity respectively [Brewer et al., 1998; Lovell et al., 1998; Brewer et al., 1999; Barr et al., 2002].

\subsection{Geochemical Data}

[12] Several sets of data were used for this study. Whole rock chemical analyses from ODP leg 129 samples are reported in Lancelot et al. [1990] and Castillo et al. [1992]. The additional analyses from ODP leg 185 were performed on board by XRF [Plank et al., 2000] and at Boston University by ICP-AES (major elements) and ICP-MS (trace elements) (K. A. Kelley et al., The Composition of Altered Oceanic Crust at ODP Sites 801 and 1149, manuscript submitted to Geochemistry, Geophysics, Geosystems, 2002, hereinafter referred to as Kelley et al., submitted manuscript, 2002). Additional information on analytical techniques and errors can be found in Kelley et al. (submitted manuscript, 2002).

\subsection{Multi Sensor Track Natural Gamma Ray (MST-NGR) Data}

[13] NGR emission was recorded for all core sections to measure variations in radioactive counts of sample rocks during Leg 185 [Plank et al., 2000]. The NGR system records radioactive decay of ${ }^{40} \mathrm{~K},{ }^{232} \mathrm{Th}$, and ${ }^{238} \mathrm{U}$, three long-period isotopes that decay at an essentially constant rate within measurable timescales. NGR emission was measured every $10 \mathrm{~cm}$ for a 20 -s period. The NGR instrument was calibrated with a thorium source and background counts measured using a core liner filled with distilled water averaged $11.75 \mathrm{cps}$ over a 30 -min measurement period. Measurements in counts per second can be qualitatively compared to the API (American Petroleum Industry) units obtained from borehole wire line logging. Calibration tests were undertaken during Leg 185 and are described in details in Plank et al. [2000]. These have allowed us to estimate $\mathrm{K}_{2} \mathrm{O}$ concentrations (in wt.\%) from the NGR data (in count per second) in order to compare them with the logging data. This calibration assumes that the MST-NGR variations are largely because of $\mathrm{K}$ variations and was defined for the tholeiitic section of Hole 801C basement. The MST-NGR data were therefore not used to calculate an average composition of the alkali upper section of the basement.

\section{Results}

\subsection{Gamma Ray Data With Depth}

[14] $\mathrm{K}_{2} \mathrm{O}, \mathrm{U}$ and $\mathrm{Th}$ contents, extracted from the gamma ray measurements (Figure 3) indicate a general decrease in radioactivity with depth, similar to the data collected during Leg 144 where the depth profiles overlap (483-560 mbsf) [Shipboard Scientific Party, 1993; Plank et al., 2000]. Overall, there is a good match between the tool measurements and the geochemical analyses. $\mathrm{K}_{2} \mathrm{O}$ contents are high $(>2 \%)$ in the top $100 \mathrm{~m}$ of the basement, corresponding to the upper alkali lava sequence (Figure 2) [Lancelot et al., 1990; Castillo et al., 1992; Floyd and Castillo, 1992; Floyd et al., 1992; Plank et al., 2000]. There is good agreement in this section between the measured samples and the gamma ray data. In the lower section, concentrations shown by both types of data are much lower ( $<1 \%$ on average) but chemical analyses of some of the samples display higher contents (breccias, sediments and some pillow basalts). 


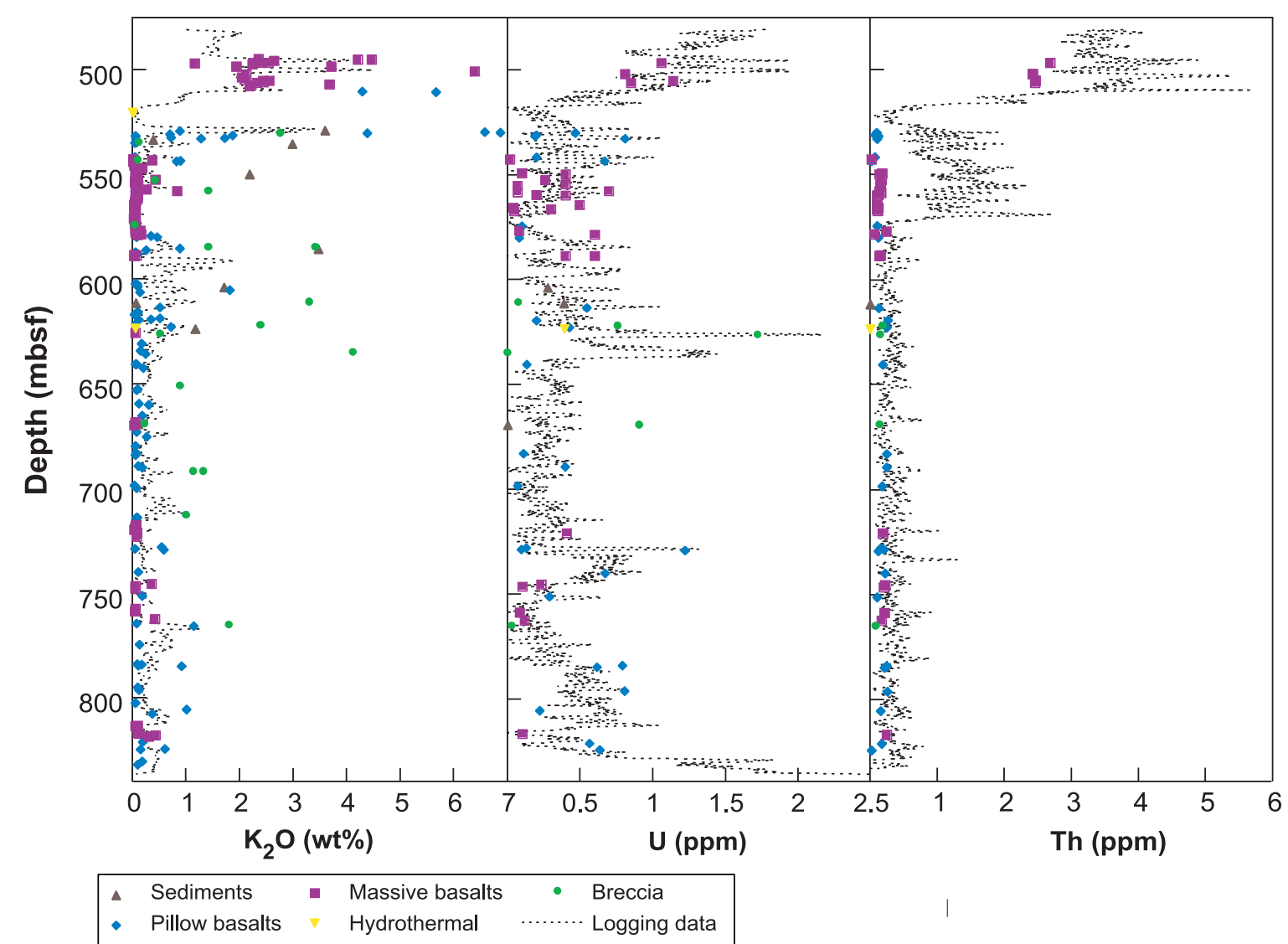

Figure 3. Plots of $\mathrm{K}_{2} \mathrm{O}$ (wt.\%), $\mathrm{U}(\mathrm{ppm})$ and $\mathrm{Th}(\mathrm{ppm})$ versus depth of gamma ray logging data and geochemical analyses of discrete samples.

The gamma ray curve does not show such high $\mathrm{K}$ concentrations but these brecciated or more altered intervals are, however, marked by peaks on the log curve.

[15] There is also a good agreement between the $\mathrm{U}$ content measured in the samples and the gamma ray logs. The overall concentrations are low, as expected for MORB (0.3 ppm on average [Staudigel et al., 1996]). The difference in absolute concentration results in a more scattered curve for the gamma ray measurements. As noticed for $\mathrm{K}_{2} \mathrm{O}$, some samples display high $\mathrm{U}$ contents, probably reflecting a high degree of alteration and the presence of carbonate veins that are hosts for $\mathrm{U}$ [Farr et al., 2001]. These intervals can be also picked up in the gamma ray curve.

[16] Th contents are high in the upper alkali lavas ( 2.5 ppm) and decrease down section with lower Th concentrations $(<1 \mathrm{ppm})$. Within a section between $525-575$ mbsf, there is a strong discrep- ancy between the very low values measured in the samples, which are usual for MORB, and the higher values reported by the tool. The source of these high thorium values is not well understood and a similar pattern of thorium concentration is observed in the Leg 144 logging data [Shipboard Scientific Party, 1993]. This inconsistency probably reflects an artefact from the spectral processing of the HNGS and NGT tools and Th concentration are not used further in this study.

\subsection{Methodology}

\subsubsection{Sample Location}

[17] One problem arising with drilling in ocean crust is that the exact sample location is lost during the drilling process. On average, a $9.5 \mathrm{~m}$ interval is drilled for each core. When recovery is $<100 \%$, it is ODP curation convention that the entire core will be shifted up to the top of the core barrel. The overall relative stratigraphy of the section is therefore 


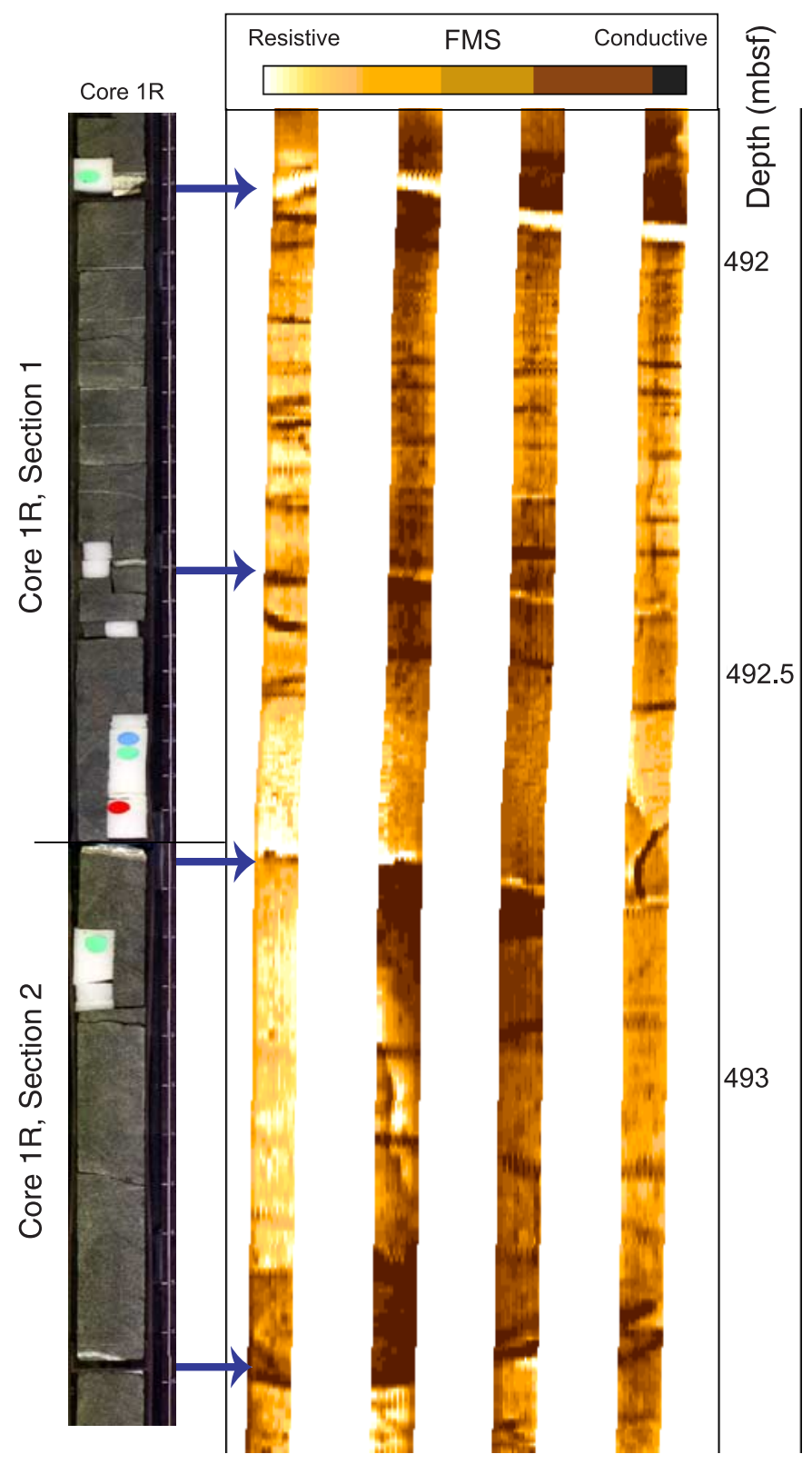

Figure 4. Example of sample relocation on core 1R, section 1 and 2. As highlighted by arrows, specific features such as veins or interpillow intervals, identified on digital images of the recovered cores and the FMS images are used to relocate the core samples. This illustrates how the FMS images were used to assess the new depth of the samples. In this case, the logging data enable to relocate section 2 with respect to section 1 and show that nothing was lost in these intervals.

maintained but the depths of the different pieces are not their true depths. In contrast, the logging tool measurements give a continuous record downhole, with absolute depths below seafloor.

[18] In order to directly compare logging data and data measured on discrete samples it is critical to relocate the samples relative to the logging depths. To do this, we have matched the FMS images with images of the recovered cores. Using specific features, such as thick veins or breccia in-tervals, on the FMS images we were able to relocate the samples within the $9.5 \mathrm{~m}$ interval drilled by that core (Figure 4). This allows the relocation of the 


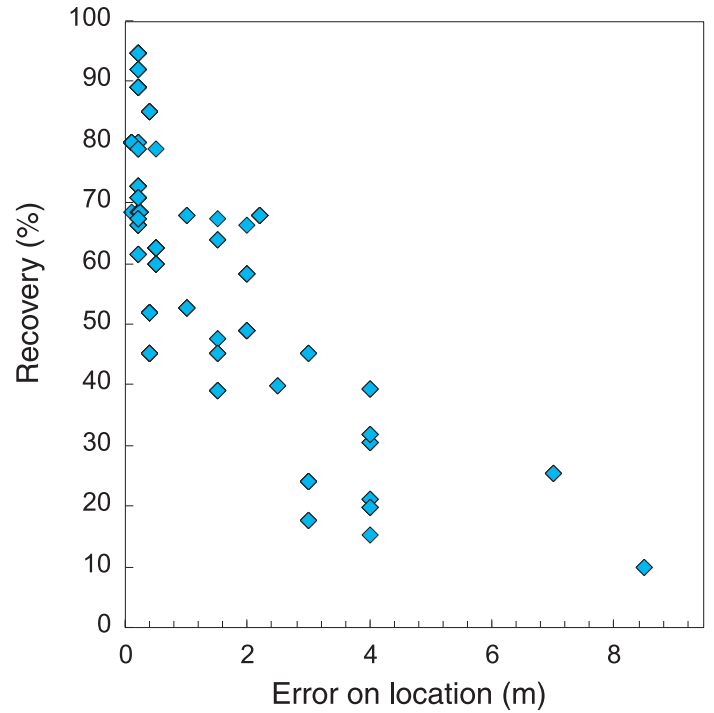

Figure 5. Plot of recovery (\%) versus the error on the sample relocation $(\mathrm{m})$. There is a clear correlation between these two parameters and the error on location increases when the recovery decreases.

different sections of the core and therefore enables us to attribute, within error, its true depth to each sample. The error on the relocation shows an inverse relationship with the recovery (Figure 5) but is also dependent on the number of identifiable features within the core, which can be used to match the core with the FMS image. For example, in a continuous interval of homogeneous massive basalts, there is limited variation within the FMS images or the rocks recovered. It is therefore difficult to accurately relocate a sample.

\subsubsection{Direct Comparison of Logging Data and Geochemical Data}

[19] Once the samples have been relocated with respect to the logging depths, the gamma ray data and the whole rock geochemical analysis for $\mathrm{K}_{2} \mathrm{O}$ and $\mathrm{U}$ can be compared directly (Figures 6 and 7). On overall the correlations between the two data sets is good indicating that the gamma ray logging tool measurements are reliable. Some scatters is observed but can be related to various factors described in the section below. The common source of error for each lithology and chemical element is the error on the sample relocation as described in the previous section.

\subsubsection{Massive Basalts}

[20] Major elements (including $\mathrm{K}_{2} \mathrm{O}$ ) were analysed on 109 samples of massive basalt [Lancelot et al., 1990; Castillo et al., 1992; Plank et al., 2000; Kelley et al., submitted manuscript, 2002]. Alkali basalts (27 samples) can easily be distinguished from the tholeiitic basalts with their $\mathrm{K}_{2} \mathrm{O}$ contents (1.2-6.4 wt. \% and $<1$ wt.\% respectively, Figure 6a). The agreement between the wire line logging and the analytical measurements for massive basalts is very good (note that the highest concentrations have the greatest scatter in Figure 6a) with most of the samples plotting on a one to one line (Figure 6a). Scatter observed within the alkali basalt, toward high values can be related to the degree of alteration of the individual rock sample. For the massive basalts with the lowest concentrations of $\mathrm{K}_{2} \mathrm{O}(<0.5$ wt.\%, Figure 6e) the correlation is weaker and the values extracted from the logging tool tend to be higher than those from the chemical analyses. Errors on the gamma ray values are estimated to $10 \%$ for $\mathrm{K}_{2} \mathrm{O}$ concentrations $<1$ wt. $\%$ and $5 \%$ for the chemical analyses (Figure 6e). However, the weaker correlation observed on Figure $6 \mathrm{e}$ indicates that these errors might be higher. This also illustrates a major difference between the two techniques. For the chemical analyses only small, very fresh samples were chosen and these yielded very low $\mathrm{K}_{2} \mathrm{O}$ contents. On the other hand, the logging tool measures a larger volume, which may include more altered portions, therefore giving higher $\mathrm{K}_{2} \mathrm{O}$ contents. Despite these differences between the two data sets this do not, in our opinion, rule out the method. In fact, $\mathrm{K}_{2} \mathrm{O}$ concentrations in massive basalts are very low and their influence on the average composition calculated per core (see below) will be low. For example, using data reported in Table 1 (Core 12R) an increase of $100 \% \mathrm{~K}_{2} \mathrm{O}$ on the average massive basalt composition (from 0.05 wt. $\%$ to 0.1 wt.\%) will result only in a $10 \%$ difference in the average $\mathrm{K}_{2} \mathrm{O}$ content for the core (from $0.29 \%$ to $0.32 \%$ using the corederived proportions and from $0.79 \%$ to $0.83 \%$ using the log-derived proportions, Table 1).

[21] $\mathrm{U}$ was analysed on 36 massive basalt samples (9 alkali basalts and 25 tholeiites, Figure 7a) [Castillo et al., 1992; Kelley et al., submitted 

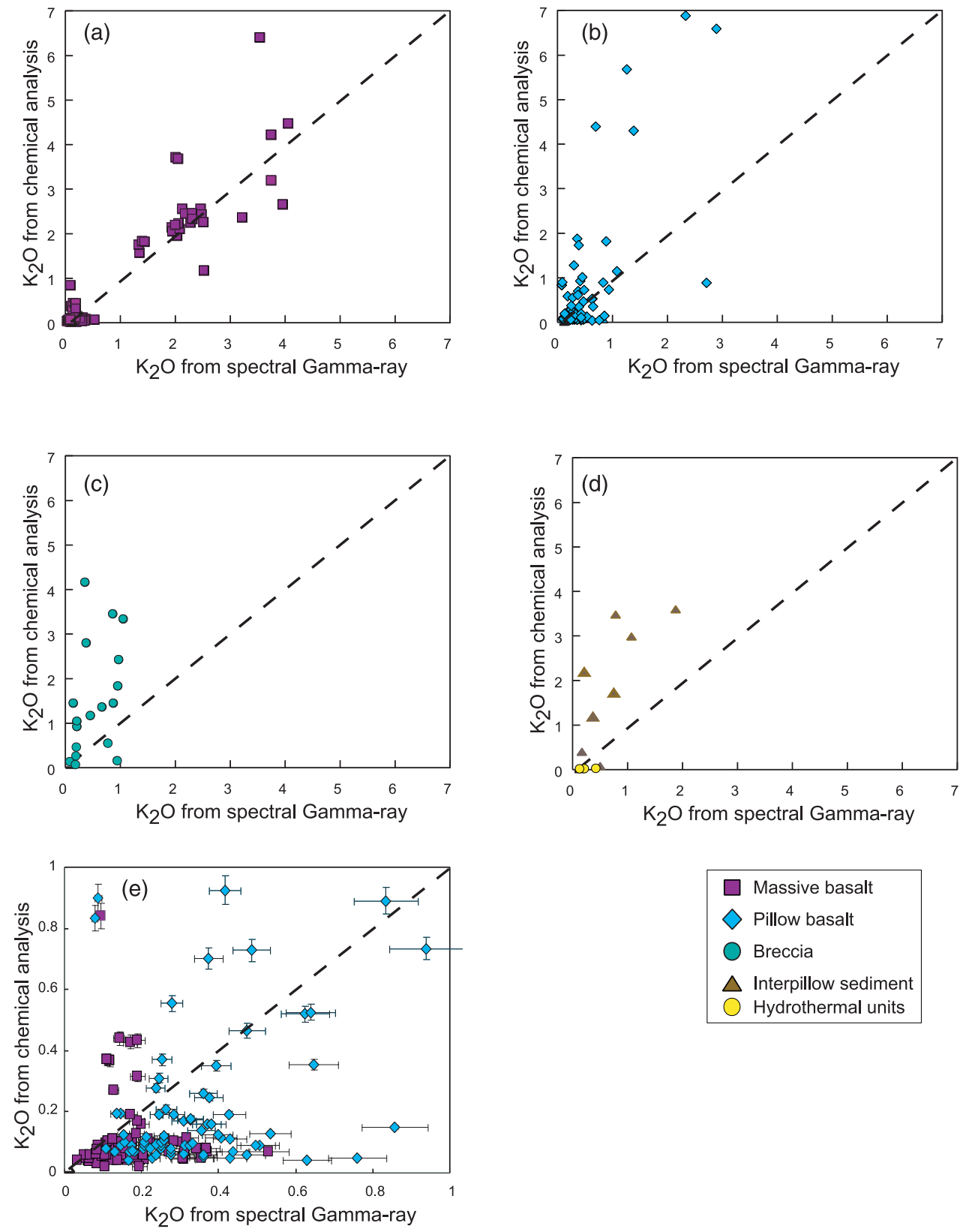

$\square$ Massive basalt
$\checkmark$ Pillow basalt
Breccia
$\triangle$ Interpillow sediment
Hydrothermal units

Figure 6. Plots of $\mathrm{K}_{2} \mathrm{O}$ (wt.\%) measured on discrete samples versus $\mathrm{K}_{2} \mathrm{O}$ (wt.\%) measured by the gamma ray logging tool for the different rock types identified during Leg 185. (a) Massive basalts; (b) pillow basalts; (c) breccia; (d) sediments and hydrothermal units; (e) zoom of plots Figures 6a and 6b. Errors bars represent 5\% error for the chemical analyses and $10 \%$ error for the gamma ray data.

manuscript, 2002]. As for $\mathrm{K}_{2} \mathrm{O}$, the alkali basalts are easily distinguished by higher $\mathrm{U}$ concentrations ( $\mathrm{U}>\sim 1 \mathrm{ppm}$ ) and the tholeiites display low $\mathrm{U}$ contents $(\mathrm{U}<\sim 0.5 \mathrm{ppm}$ ) (Figure 7a). The correlation between the chemical analyses and the logging data is fairly good given that the detection limit of the tool is usually estimated to $1 \mathrm{ppm}$. The gamma ray data tend to be higher than the chemical analyses, which might also be related to the averaging effect of the logging tool.

\subsubsection{Pillows Basalts}

[22] $\mathrm{K}_{2} \mathrm{O}$ was measured on 90 samples of pillow basalt [Lancelot et al., 1990; Castillo et al., 1992; 

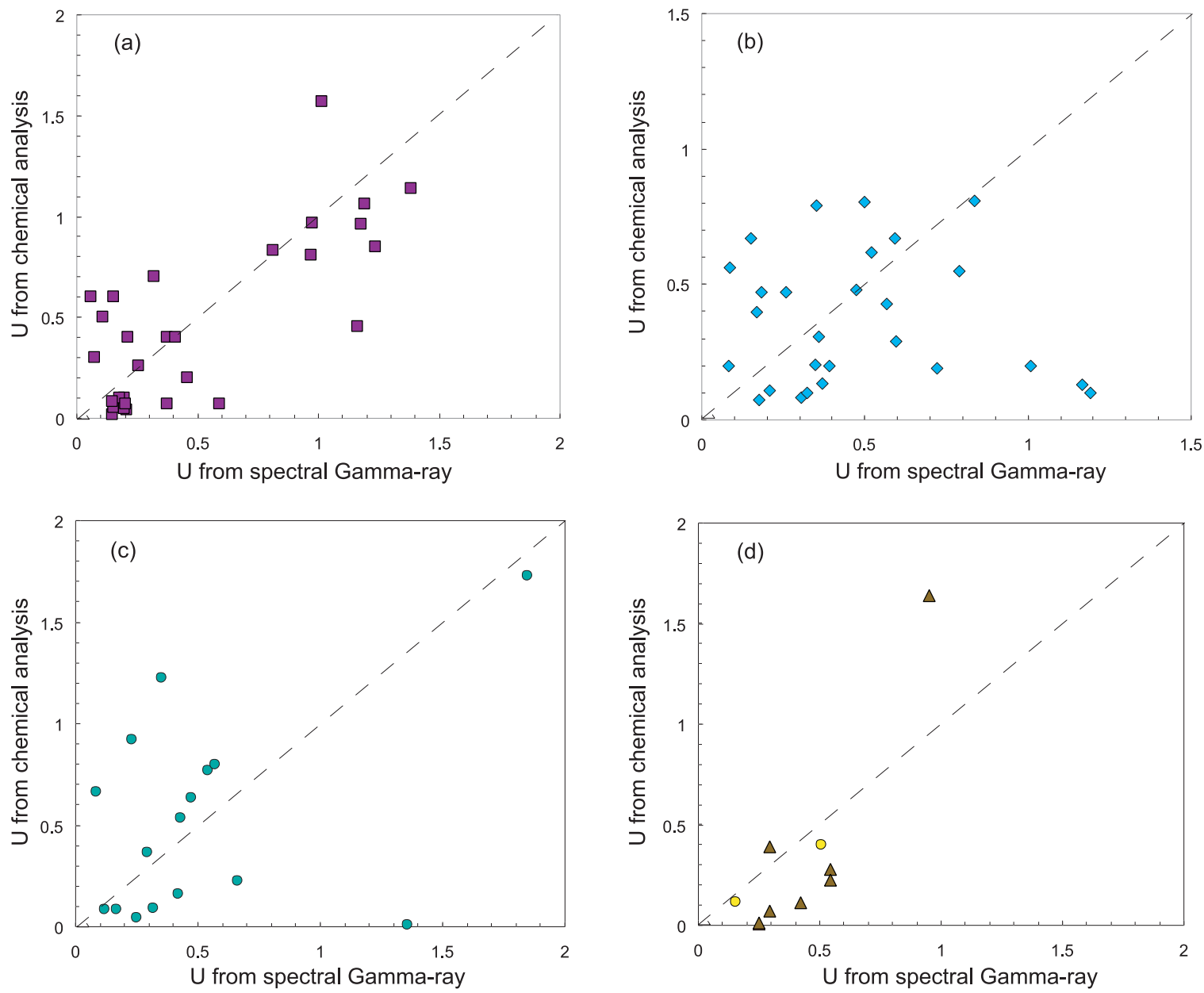

\begin{tabular}{|l}
$\square$ Massive basalt \\
$\diamond$ Pillow basalt \\
$\bigcirc$ Breccia \\
$\triangle$ Interpillow sediment \\
Hydrothermal units
\end{tabular}

Figure 7. Plots of $U(\mathrm{ppm})$ measured on discrete samples versus $U(\mathrm{ppm})$ measured by the gamma ray logging tool for the different rock types identified during Leg 185. (a) Massive basalts; (b) pillow basalts; (c) breccia; and (d) sediments and hydrothermal units.

Plank et al., 2000; Kelley et al., submitted manuscript, 2002]. The $\mathrm{K}_{2} \mathrm{O}$ contents measured on discrete samples of pillow basalts cover a larger range than for massive basalts, from $\sim 0.1 \mathrm{wt} . \%$ up to 7 wt.\%. The agreement between the two datasets is fairly good for the low concentrations $\left(0<\mathrm{K}_{2} \mathrm{O}<1\right.$ $\mathrm{w} \%$ ) (Figures $6 \mathrm{~b}$ and $6 \mathrm{e}$ ). For the highest concentrations, the $\mathrm{K}_{2} \mathrm{O}$ contents measured on individual samples are higher than those reported by the gamma ray tool (Figure 6b). For concentrations below $0.5 \mathrm{wt} . \%$, the concentrations measured by the logging tool are higher than those obtained from the chemical analyses, as observed for the massive basalts (Figure 6e).

[23] U was analysed on 26 samples [Castillo et al., 1992; Kelley et al., submitted manuscript, 2002] from the tholeiitic section. As observed for the 
Table 1. Example of Calculation for Core $12 \mathrm{R}^{\mathrm{a}}$

\begin{tabular}{|c|c|c|c|c|c|}
\hline Lithology & $\begin{array}{l}\text { Core-derived } \\
\text { proportions }(\%)\end{array}$ & $\begin{array}{c}\text { Proportions } \\
\text { upscaled to } 100 \%\end{array}$ & $\begin{array}{c}\text { Log-derived } \\
\text { proportions }(\%)\end{array}$ & $\mathrm{K}_{2} \mathrm{O}$ content $(\%)$ & $n$ \\
\hline Breccia & 1.6 & 3.1 & 25.6 & 2.44 & 2 \\
\hline Massive basalt & 44 & 84.7 & 44 & 0.05 & 3 \\
\hline Pillow & 4.2 & 8 & 28.2 & 0.25 & 6 \\
\hline Sediment & 2.2 & 4.2 & 2.2 & 3.48 & 1 \\
\hline Total & 52 & 100 & 100 & & \\
\hline Non recovered & 48 & & & & \\
\hline \multicolumn{6}{|c|}{$\mathrm{K}_{2} \mathrm{O}$ average for core $12 \mathrm{R}(\%)$} \\
\hline From core & 0.29 & & & & \\
\hline From logs & 0.79 & & & & \\
\hline Logging data & 0.76 & & & & \\
\hline
\end{tabular}

${ }^{\mathrm{a}} n$ is the number of samples used.

massive basalts, the correlation between the two data sets is less well defined for $\mathrm{U}$ than for $\mathrm{K}$ (Figure 7b).

\subsubsection{Breccia}

[24] $\mathrm{K}_{2} \mathrm{O}$ was measured on 21 samples of volcanic breccia [Lancelot et al., 1990; Castillo et al., 1992; Plank et al., 2000; Kelley et al., submitted manuscript, 2002]. As observed for pillow basalts, $\mathrm{K}_{2} \mathrm{O}$ concentrations measured on discrete samples display a large range $(\sim 0.1->4 \mathrm{wt} \%)$ and are higher than those reported by the logging tool (Figure 6c). There is, however, a close correlation between the nature of the samples and the difference between the two data sets. Samples, which show the highest $\mathrm{K}_{2} \mathrm{O}$ concentrations in the chemical analyses, are also those that contain more matrix than basalt clasts (see also discussion and Plank et al. [2000] for a full description of the samples).

[25] U was analysed on 16 samples from the tholeiitic section [Castillo et al., 1992; Kelley et al., submitted manuscript, 2002]. The correlation between the two data sets is fairly good as most samples plot close to the one to one line (Figure 7c).

\subsubsection{Sediments and Hydrothermal Units}

[26] $\mathrm{K}_{2} \mathrm{O}$ was measured on 10 samples of interpillow sedimentary material and 4 samples from both upper and lower hydrothermal units [Lancelot et al., 1990; Plank et al., 2000; Kelley et al., submitted manuscript, 2002]. The sediments samples display similar trends to those observed for pillow basalts and breccia. $\mathrm{K}_{2} \mathrm{O}$ contents range from $\sim 0.1$ wt. $\%$ to $\sim 4$ wt. $\%$ and $\mathrm{K}_{2} \mathrm{O}$ contents calculated from the logging tool data are lower than those measured on discrete samples (Figure 6d). All the samples from the hydrothermal units plot within a narrow range and both techniques yielded very low $\mathrm{K}_{2} \mathrm{O}$ contents $(<0.1 \mathrm{wt} . \%$ for the chemical analyses and $<0.5$ wt. $\%$ for the gamma ray tool) (Figure 6d). Given the very small number of samples, it is difficult to give a reliable interpretation on the hydrothermal units.

[27] U was analysed on 7 sediment samples and 2 hydrothermal samples [Kelley et al., submitted manuscript, 2002]. Given the low U contents of these samples, the correlation between the two data sets is reasonably good for both the sediments and the hydrothermal units (Figure 7d).

\subsubsection{Average $\mathrm{K}_{2} \mathrm{O}$ and $\mathrm{U}$ Contents Per Core}

[28] To estimate the $\mathrm{K}_{2} \mathrm{O}$ and $\mathrm{U}$ budgets in Hole $801 \mathrm{C}$ basement, average contents were calculated for each core using the expanded core-derived proportions, the log-derived proportions and the gamma ray logging data. For each core an average composition is obtained by a mass balance calculation. $\mathrm{K}_{2} \mathrm{O}$ contents calculations for core $12 \mathrm{R}$ are reported in Table 1 and Figure 8 as an example. The average chemical composition of samples from each lithology (Table 1) is first balanced by the proportions of each lithology recovered in the core and scaled to $100 \%$ recovery (Figure 8 , Table 1). Then, using the core-log integration results, a rock type is attributed to the un-recovered interval and 


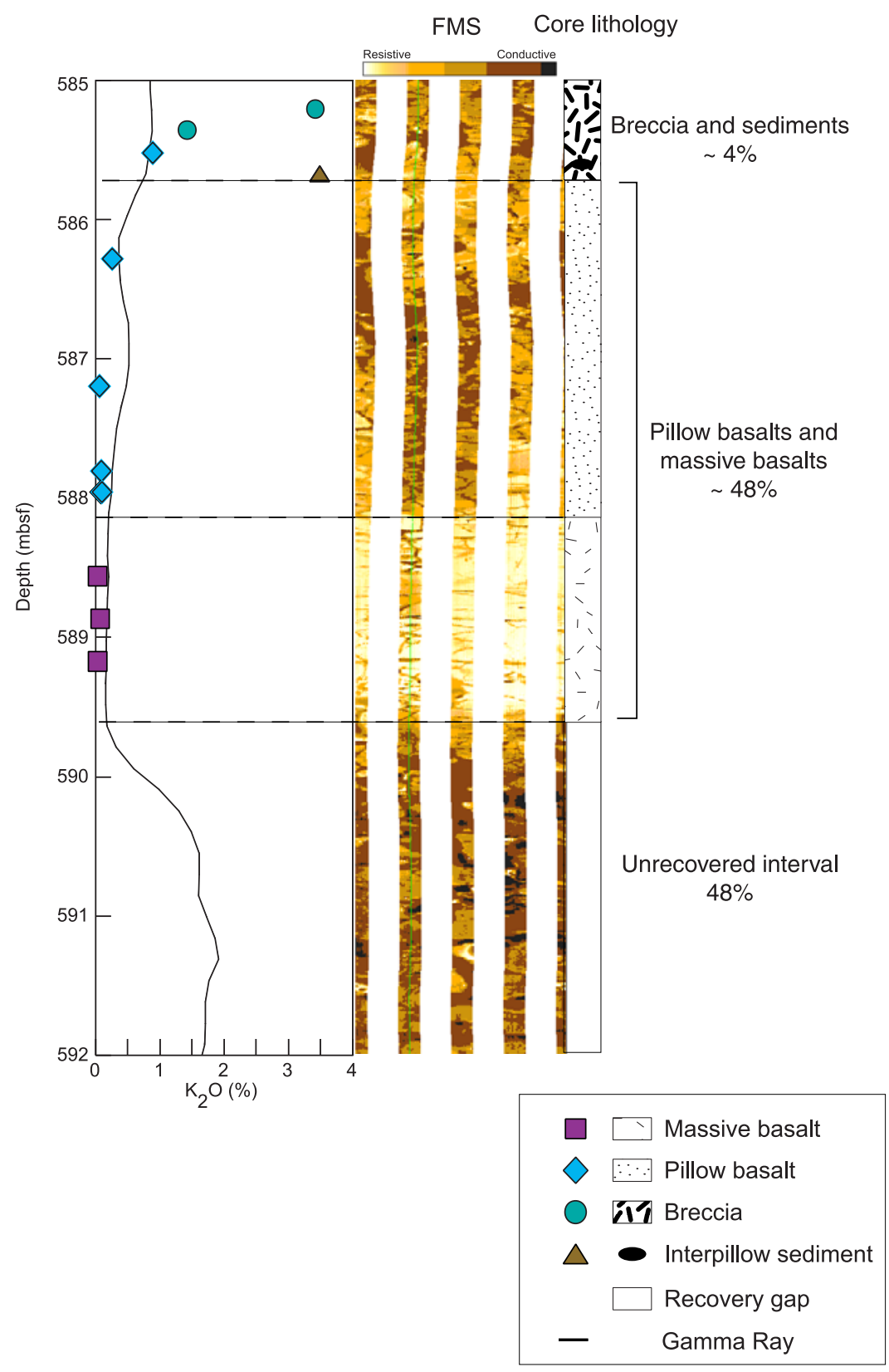

Figure 8. Example (core $12 \mathrm{R}$ ) of $\mathrm{K}_{2} \mathrm{O}$ average content calculation per core. The core lithology, the FMS images, the gamma ray data and geochemical analyses are reported versus depth. The FMS images and the gamma ray data are used to identify the missing rock type(s). Then the geochemical analyses of recovered samples are used to calculate an average $\mathrm{K}_{2} \mathrm{O}$ content for the core together with an average of $\mathrm{K}_{2} \mathrm{O}$ content measured by the gamma ray tool over this specific depth interval.

new proportions for each lithology are calculated (Table 1) [Barr et al., 2002]. A new average concentration is then calculated using the same chemical compositions and balanced by log-derived proportions (Figure 8, Table 1). The contents from the gamma ray logging tool were calculated by averaging all the measurements over an interval specific to each core. (Figure 8, Table 1). If all the different lithologies were not recovered or analysed for a particular core, then average compositions of the different rock types were used instead. These calculations were performed on all cores for $\mathrm{K}_{2} \mathrm{O}$, except cores $3 \mathrm{R}$ and $13 \mathrm{R}$ because of their very low recovery (respectively $10 \%$ and $3.7 \%$ ) (Table 2 ). 


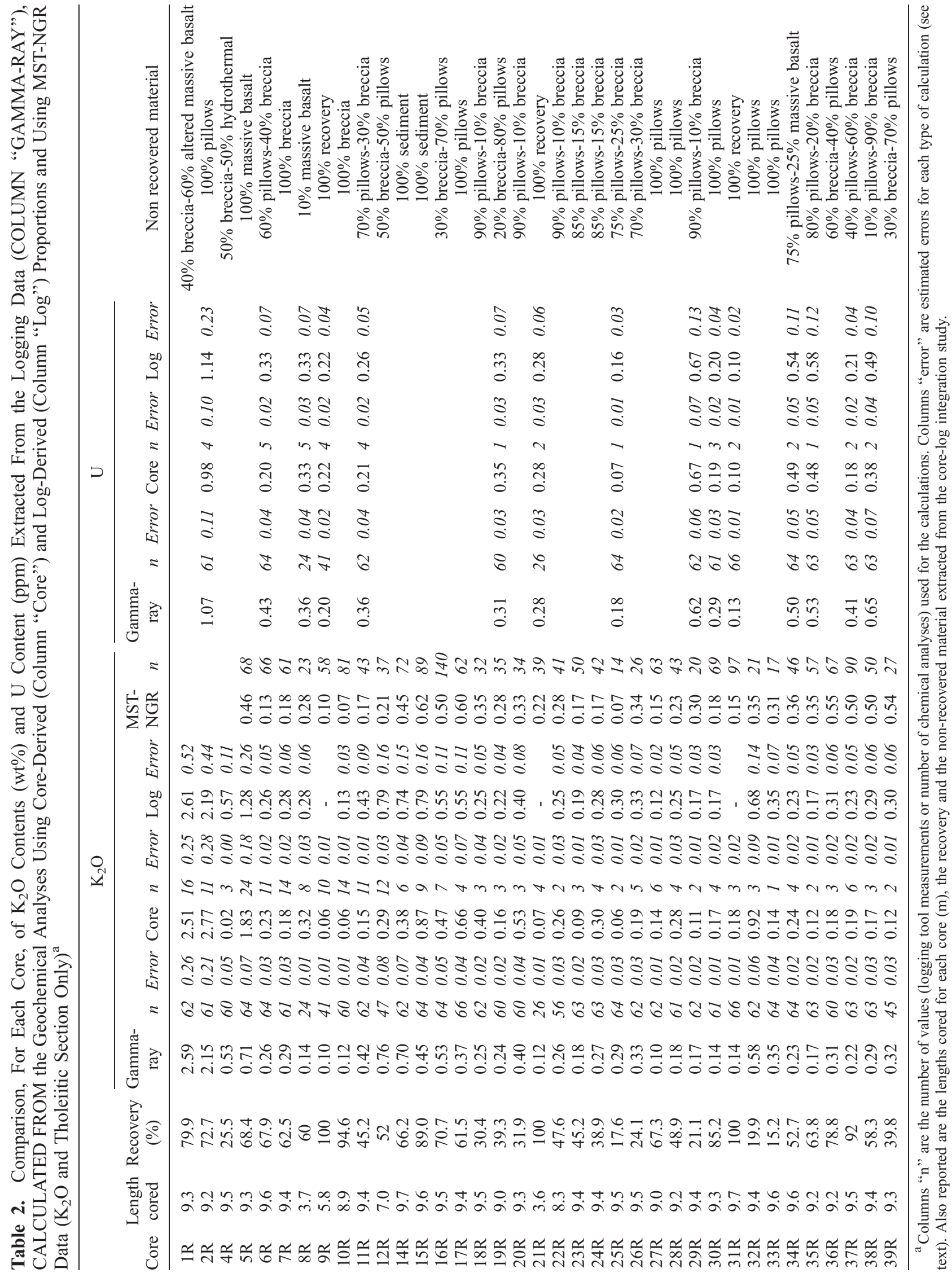


Average U concentrations were calculated on 15 cores where enough chemical analyses were available (Table 2). Errors on this type of calculations are difficult to estimate as they depend on various factors. For the average compositions calculated using the core derived proportions the main sources of error are (a) the analytical error on the chemical analyses and (b) the identification of each lithology within the core and their proportions, calculated from the core images. The number of samples available per core for the calculations is an additional source of error as average compositions were used when all the lithologies were not analysed in a core. Errors on this set of calculations were estimated to be slightly higher than the analytical error and set at $10 \%$ (Table 2). For the second set of calculations, performed with the log-derived proportions, errors are to be higher than the previous ones, as they also depend on our ability to identify the missing lithologies. This also depends on the recovery, as the error on the un-recovered material will decrease with the recovery increasing. Errors for these concentrations were estimated to be twice higher than for the previous calculations and set at $20 \%$ (Table 2). Finally, errors on the logging data measurement alone are usually estimated to $10 \%$ for concentrations below $1 \%$ for $\mathrm{K}_{2} \mathrm{O}$ and $10 \mathrm{ppm}$ for $\mathrm{U}$, which are the range of most of the Hole 801C basement section (Table 2).

\subsubsection{MST-NGR Data}

[29] For a comparison, we also calculated $\mathrm{K}_{2} \mathrm{O}$ concentrations for each core using the MST-NGR data measured during Leg 185 [Plank et al., 2000]. These were obtained simply by averaging all the data measured per core. We used the calibration defined during Leg 185 for K [Plank et al., 2000] and applied it on the tholeiitic section of Hole $801 \mathrm{C}$ basement (Table 2).

\section{Discussion}

\subsection{Can We Use Gamma Ray Data as a Proxy for Chemical Composition Downhole?}

[30] The average $\mathrm{K}_{2} \mathrm{O}$ contents per core, calculated with the core-derived proportions are more scat- tered than those calculated using the log-derived proportions (Figure 9a). The latter plot closely on a one to one line, indicating a close agreement between the gamma ray data and $\mathrm{K}_{2} \mathrm{O}$ contents calculated from the samples using the new proportions, adjusted for missing intervals (Figure 9a). The average concentrations per core, calculated using the MST-NGR data are also more scattered than those calculated using log-derived proportions. These concentrations plot close to the contents calculated using the core-derived proportions, although usually closer to the 1:1 line (Figure 9a). This result can be expected, as the MST-NGR data, measured on the recovered cores, also do not take into account the missing intervals. It demonstrates, however, the reliability of MST-NGR data and their close agreement with the chemical compositions of the samples. It also shows an averaging effect related to this type of data and comparable to the one observed for logging data. The volume of core analysed with the MST-NGR tool will be larger than the discrete sample measured by chemistry and therefore variations in the chemical compositions reported by the MST-NGR data will be less extreme.

[31] Most of the $\mathrm{K}_{2} \mathrm{O}$ contents calculated with the core-derived proportions are lower than the content reported by the wire line logging tool (Figure 9a). This is related to two main effects: (a) the logging tool overestimates the $\mathrm{K}_{2} \mathrm{O}$ contents or (b) using the core-derived proportions results in a bias against $\mathrm{K}_{2} \mathrm{O}$-rich rock types. The second explanation is likely as potassium will be more abundant in the most altered part of the basement section as well as in breccia and interpillow material [Alt et $a l ., 1998$ ] and these brittle rock types are preferentially lost during drilling process [Brewer et al., 1998 , 1999]. It follows that average $\mathrm{K}_{2} \mathrm{O}$ content of the cores will be underestimated if the core-derived proportions of the different rock types are used.

[32] It should be also noted, that some cores show average $\mathrm{K}_{2} \mathrm{O}$ contents derived from the chemical analyses that are higher than the $\mathrm{K}_{2} \mathrm{O}$ content reported by the logging tool (Figure 9a). This can be observed on both sets of calculations, using either core-derived or log-derived proportions and cannot be related to a bias in the lithological proportions. It 

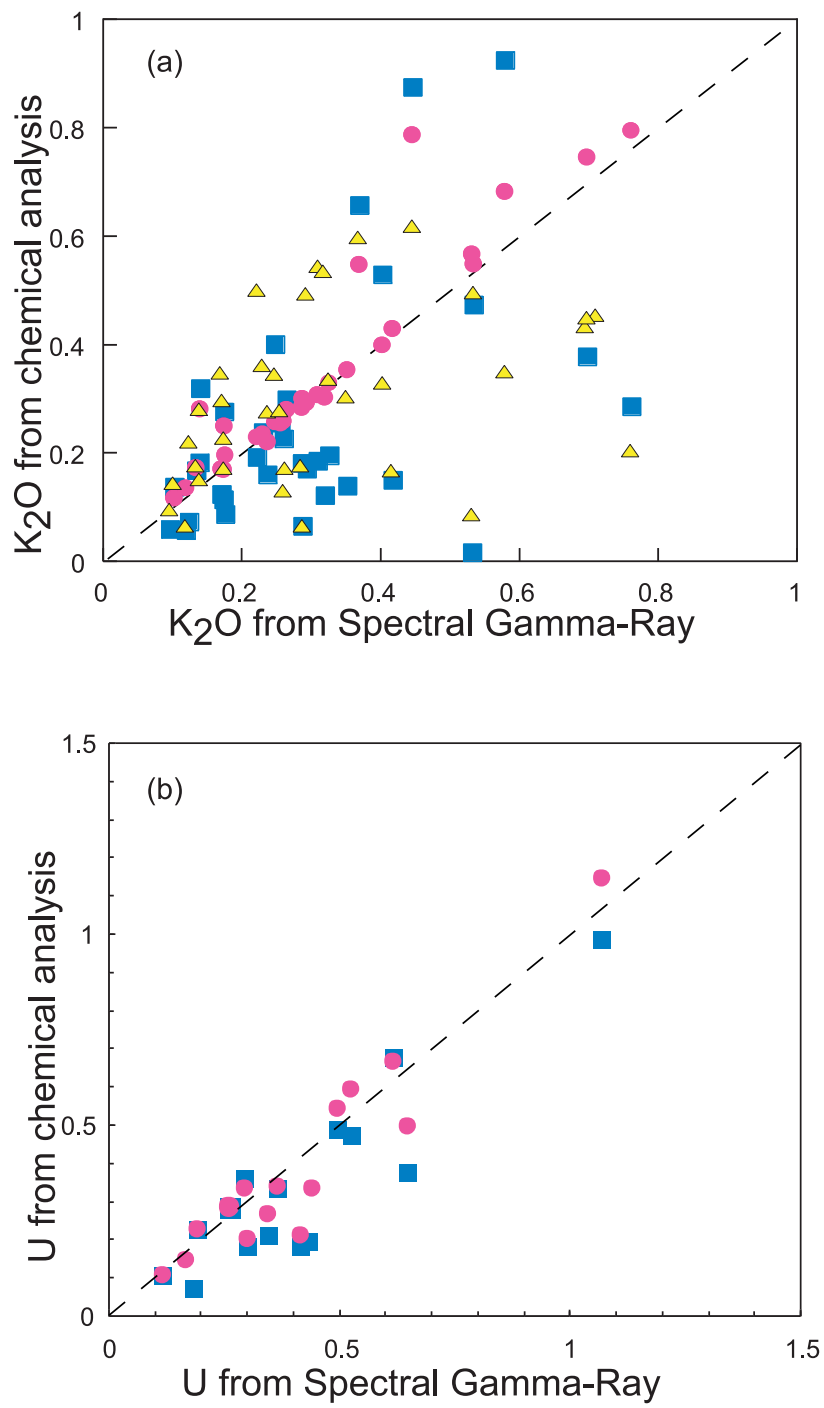

Calculated with core-derived proportions

- Calculated with log-derived proportions

$\triangle$ Calculated with core-derived proportions and MST-NGR data

Figure 9. Plot of the average (a) $\mathrm{K}_{2} \mathrm{O}$ (wt.\%) content per core derived from the geochemical analyses versus the $\mathrm{K}_{2} \mathrm{O}$ (wt.\%) content per core derived from the gamma ray logging tool measurements and (b) $\mathrm{U}$ (ppm) content per core derived from the geochemical analyses versus the $U(\mathrm{ppm})$ content per core derived from the gamma ray logging tool measurements. Each data point is representative of a core. The blue squares were calculated using the rock types proportions derived from the recovered cores and the pink circles were calculated using the lithology proportions derived from the core-log integration study. The yellow triangles reported on Figure 9a were calculated using the core-derived proportions and the MST-NGR data collected during Leg 185.

therefore must reflect a difference in the absolute $\mathrm{K}_{2} \mathrm{O}$ content measured by the gamma ray tool and the chemical analyses. In this case, the question is whether the gamma ray logging tool underestimate the potassium content in the section or if the $\mathrm{K}_{2} \mathrm{O}$ contents measured on discrete samples and used for a specific lithology are an overestimation.

[33] Some samples, mainly breccia, display higher $\mathrm{K}_{2} \mathrm{O}$ contents than measured by the logging tool, 


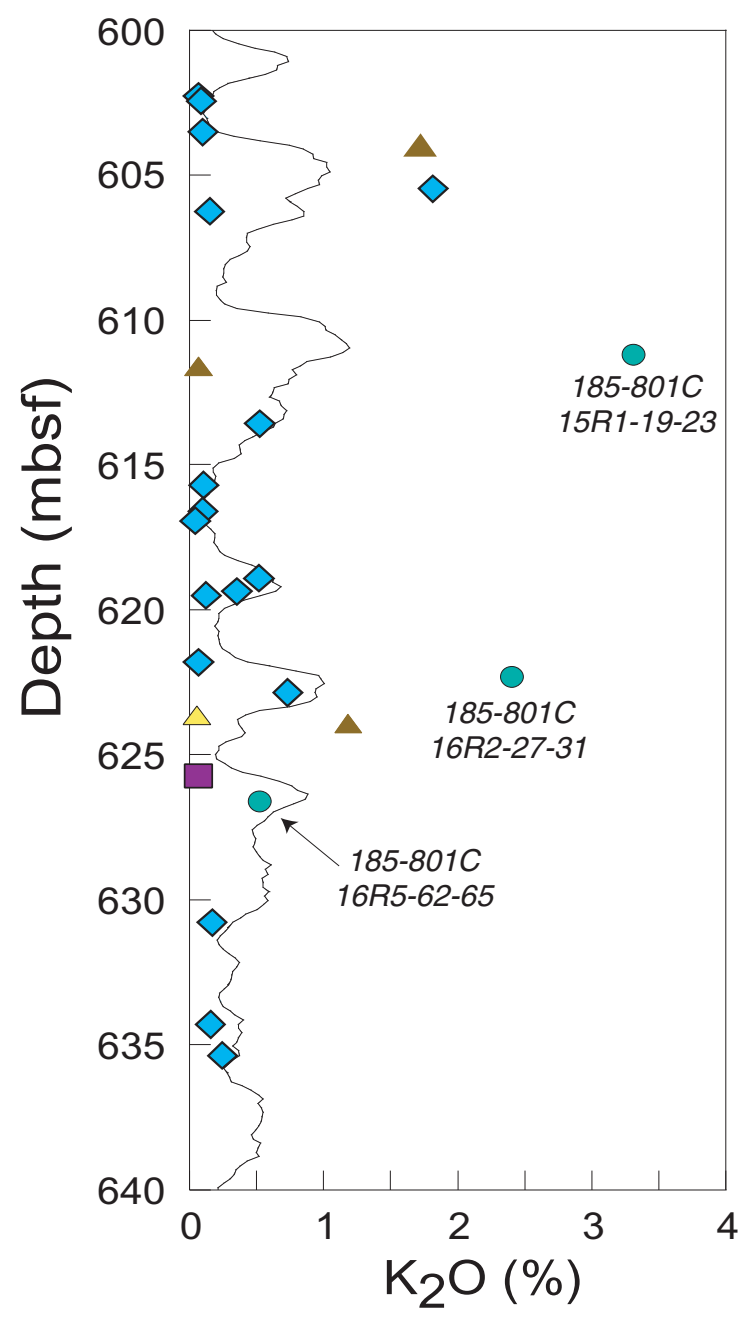

Figure 10. Plot of $\mathrm{K}_{2} \mathrm{O}$ contents of discrete samples and gamma ray data versus depth for the interval from 600 to 640 mbsf.

although the gamma ray curve does show peaks for these intervals (Figure 10, samples 185-801C15R1-19-23 and 16R2-27-31, see also Figure 6). These samples comprise a matrix composed of highly altered basalt, carbonates, celadonite and clay minerals, preferentially enriched in $\mathrm{K}_{2} \mathrm{O}$, and a small proportion of basalt clasts. In contrast, the third breccia sample (Figure 9, 185-801C-16R5$62-65)$ is mainly composed of basaltic clasts $(90 \%)$ with only a small amount of matrix and its $\mathrm{K}_{2} \mathrm{O}$ content is in close agreement with the tool measurement. This difference can either be related to the logging tool itself, which measures the gamma ray counts over a larger volume than the analysed sample or to the samples themselves. Some breccia and pillow basalts samples have extreme compositions and are probably not highly representative of the overall composition of these rock types in 
the basement section. Other samples, in which basalt and matrix proportions are less extreme, are probably more representative of the overall composition (Figure 10). This can explain most of the differences observed between the chemical analyses and the gamma ray data for the pillow basalts, sediments and breccias (Figure 6). Despite uncertainties related to the radius of investigation of the tool and its averaging effect, this indicates that the gamma ray tool is well calibrated in basement sections and logging data can be used to accurately estimate the overall $\mathrm{K}_{2} \mathrm{O}$ content in a borehole.

[34] The same features, as for $\mathrm{K}_{2} \mathrm{O}$, can be observed on the $\mathrm{U}$ calculations (Figure $9 \mathrm{~b}$ ). The average compositions per core calculated using corederived proportions are slightly more scattered than those calculated using log-derived proportions. The latter also plot close to the one to one line (Figure $9 \mathrm{~b}$ ) and also demonstrate the reliability of the method. The concentrations calculated using the core-derived proportions are also slightly lower than the others and indicate the same bias toward U-rich lithologies, as observed on the $\mathrm{K}_{2} \mathrm{O}$ calculations. The bias toward high concentrations observed for $\mathrm{K}_{2} \mathrm{O}$ is not observed for $\mathrm{U}$ (Figure $9 \mathrm{~b}$, see also Figure 7). A ready explanation to this is found in the small contrasts in $U$ concentrations between the different lithologies. The range of $U$ concentrations in all lithologies are comparable and no extreme compositions are found in contrast to the $\mathrm{K}_{2} \mathrm{O}$ data. The sample data are therefore probably more representative of the different lithologies. We can conclude that the gamma ray tool is also fairly well calibrated and that $U$ data can be used as a further constraint on the chemical composition of a basement section.

[35] Despite relatively large errors on the calculations (up to $20 \%$ ), mainly dependent on our ability to interpret the logging data and to recognise the missing lithologies, our results show that this method can be used with confidence to estimate the $\mathrm{K}_{2} \mathrm{O}$ and $\mathrm{U}$ contents of a basement section. Furthermore, we demonstrate that the logging data are well calibrated and these results can be directly used to estimate the composition of the altered crust in term of $\mathrm{K}$ and $\mathrm{U}$.
[36] This method also highlights the difficulty of choosing representative samples to use in a "composite" sample method. A major approach of ODP Leg 185 is to use such samples, which are a physical mixture of different rock types [Staudigel et al., 1996; Plank et al., 2000] to estimate the overall composition of the basement recycled in the Marianna subduction zone. The principal difficulty when preparing these composites will be first to choose the appropriate samples and then to choose in which proportions to mix them. If the samples are not representative of each rock type, but have extreme compositions, then neither of the corederived or log-derived proportions will be representative. This is particularly critical for high $\mathrm{K}$ lithologies like breccia samples. Using the corederived proportions may result in an underestimation of the concentrations but the use of log-derived proportions may also entrain an overestimation of the concentrations in the basement. However, the core-log-geochemical integration method is only applicable, so far, to two chemical elements, $\mathrm{K}$ and $\mathrm{U}$ in contrast to the composite sample approach which allow to analyse all the chemical elements as well as isotope compositions. A combination of these two methods is required to fully estimate the composition of the oceanic crust. This can be undertaken if samples are chosen to be representative of an average rock type by checking their composition against logging data and if enough samples of each rock type are analysed such that the range in composition is accurately represented. In this case, the log-derived proportions should be used to prepare the composite.

\subsection{Oceanic Crust Composition and Impact on Flux Calculations}

[37] The calculations performed enable average $\mathrm{K}_{2} \mathrm{O}$ and $\mathrm{U}$ contents for the basement section drilled at Hole $801 \mathrm{C}$ to be calculated (Table 3). These estimates are important both for our understanding of the average composition of altered oceanic crust and in term of chemical fluxes recycled into subduction zones. For these two purposes we used two different estimates of the drilled section at Hole $801 \mathrm{C}$. The upper alkali section is younger than the tholeiitic section and 
Table 3. Summary of $\mathrm{K}_{2} \mathrm{O}$ Contents (wt.\%) and U Contents (ppm) Calculated From the Gamma Ray Data

\begin{tabular}{|c|c|c|c|c|c|c|c|}
\hline & \multicolumn{4}{|c|}{$\mathrm{K}_{2} \mathrm{O}$} & \multicolumn{3}{|c|}{$\mathrm{U}$} \\
\hline & $\underset{\text { data }}{\text { Gamma ray }}$ & $\begin{array}{l}\text { Core-derived } \\
\text { proportions }\end{array}$ & $\begin{array}{c}\text { Log-derived } \\
\text { proportions }\end{array}$ & MST-NGR $^{b}$ & $\underset{\text { data }}{\text { Gamma ray }}$ & $\begin{array}{l}\text { Core-derived } \\
\text { proportions }\end{array}$ & $\begin{array}{c}\text { Log-derived } \\
\text { proportions }\end{array}$ \\
\hline Alkali upper sequence & 2.10 & 2.54 & 2.11 & & 1.29 & $0.98^{\mathrm{d}}$ & $1.14^{\mathrm{d}}$ \\
\hline Tholeiitic sequence & 0.35 & 0.30 & 0.36 & 0.30 & 0.41 & 0.30 & 0.33 \\
\hline Tholeiite and alkali sections & 0.47 & 0.34 & 0.51 & & $0.50 / 0.42^{\mathrm{c}}$ & 0.34 & 0.39 \\
\hline
\end{tabular}

${ }^{\mathrm{a}}$ The MST-NGR data and the average composition of each core reported in Table 1 . The upper alkali lava sequence comprises mainly cores $1 \mathrm{R}$ and $2 \mathrm{R}$. The logging data were used until $515 \mathrm{mbsf}$. The tholeiite sequence is from core $4 \mathrm{R}$ to $39 \mathrm{R}$ (logged interval).

${ }^{\mathrm{b}}$ MST-NGR data from core $5 \mathrm{R}$ to $39 \mathrm{R}$.

${ }^{\mathrm{c}} 0.50 \mathrm{ppm}$ represents the average of all U-gamma ray data over the logged interval while $0.42 \mathrm{ppm}$ is the average of U-gamma ray data for the 15 cores used in the calculations.

${ }^{\mathrm{d}}$ These calculations comprise only core $2 \mathrm{R}$.

may results from off axis magmatism. We therefore considered that only the tholeiitic section recovered was representative of a "normal" oceanic crust and could therefore be used to estimate the average composition of altered oceanic crust. On the other hand, to calculate the chemical fluxes recycled into the Marianna subduction zone we integrated the alkali basalts into the calculations as both these sections are to be subducted.

\subsubsection{Composition of the Altered Oceanic Crust}

[38] Previous calculations using NGT and MSTNGR data indicate average $\mathrm{K}_{2} \mathrm{O}$ concentrations of 0.36 wt. $\%$ and 0.31 wt. $\%$ respectively for the tholeiitic section [Plank et al., 2000]. We used the average core compositions (Table 2) to calculate new average $\mathrm{K}_{2} \mathrm{O}$ and $\mathrm{U}$ contents for the tholeiitic sequence of Hole $801 \mathrm{C}$ (Table 3). The concentrations extracted from the gamma ray data values and calculated with the log-derived proportions are in very good agreement with respectively 0.35 wt. $\%$ and 0.36 wt. $\%$ for $\mathrm{K}_{2} \mathrm{O}$ and $0.41 \mathrm{ppm}$ and $0.33 \mathrm{ppm}$ for $\mathrm{U}$. Both $\mathrm{K}_{2} \mathrm{O}$ and $\mathrm{U}$ concentrations calculated with the core-derived proportions are lower than those extracted from the gamma ray data or calculated with the log-derived proportions as well as $\mathrm{K}_{2} \mathrm{O}$ concentrations calculated using average MST-NGR data (Table 3). As noticed before, the altered lithologies, such as breccia, are preferentially lost during the drilling and using core-derived proportions results in an underestimation of these rock types and an underestimation of the overall $\mathrm{K}$ and $\mathrm{U}$ contents down- hole. The difference in average $\mathrm{K}_{2} \mathrm{O}$ and $\mathrm{U}$ contents for the tholeiitic section is however relatively small given the errors associated with the various type of calculation ( 0.30 vs. $0.36 \mathrm{wt} . \%$ for $\mathrm{K}_{2} \mathrm{O}$ and 0.30 vs. 0.33 ppm for $\mathrm{U}$, Table 3).

[39] Overall, our results indicate that average $\mathrm{K}_{2} \mathrm{O}$ content of altered oceanic crust is slightly higher than estimated from core-only geochemical calculations. More importantly, these values are different than those measured on the composite samples. The $\mathrm{K}_{2} \mathrm{O}$ content of the "super composite" sample prepared during Leg 185 is 0.62 wt.\% (Kelley et al., submitted manuscript, 2002), which is much higher than our estimates but is comparable to the one reported for DSDP/ODP Sites 417 and $418\left(\mathrm{~K}_{2} \mathrm{O} 0.56\right.$ wt.\%, [Staudigel et al., 1996]). The difference is less significant in term of $U$ as the concentration of the "super composite" sample is $0.39 \mathrm{ppm}$. These high values highlight the effects of choosing unrepresentative end-members samples with high $\mathrm{K}$ contents, which disproportionably increase the composite concentrations.

\subsubsection{Recycled Crust Composition}

[40] To estimate the $\mathrm{K}$ and $\mathrm{U}$ budget recycled to the Marianna subduction zone, the alkali upper section of Hole $801 \mathrm{C}$ basement must be taken into account as well as the tholeiitic section. We also calculated average $\mathrm{K}_{2} \mathrm{O}$ and $\mathrm{U}$ concentrations for the alkali section and for the all basement section comprising the alkalic cap and the tholeiites of the logged interval (Table 3 ). 
[41] Within the upper alkali section, the concentration calculated with the core-derived proportions is higher than the one derived from the logs or calculated from the log-derived proportions (Table 3). About $30 \%$ of the material was not recovered in this interval, and is interpreted as a mixture of pillows basalts and breccia. As the massive alkali basalts have higher $\mathrm{K}$ contents compared to pillow basalts and breccia, the average content of the sequence is lowered when using the log-derived proportions. All the average $U$ concentrations calculated for the alkali sections are in good agreement. It should be noted, however, that these calculations comprise only one core (Table 3) and it is therefore difficult to extrapolate to the all section. For the all logged section (tholeiite + alkali basalts), the concentrations calculated using the core-derived proportions are lower than those calculated using both the logderived proportions and the gamma ray data $(0.34$ wt. $\%$ vs. 0.51 wt. $\%$ and 0.47 wt. $\%$ respectively for $\mathrm{K}_{2} \mathrm{O}$ and 0.34 ppm vs. 0.39 and $0.42-0.50$ ppm respectively for $\mathrm{U}$, Table 3 ).

[42] Although the difference induced by the recovery was small for the tholeiite section, the difference for the all basement is more significant. It shows that the use of core-derived proportions only may induce a bias of $20-50 \%$ in our estimates of the composition of the recycled crust.

[43] These results have significant implications for $\mathrm{K}$ and $\mathrm{U}$ budgets recycled into subduction zones. For the Marianna subduction zone a convergence rate of $4.75 \mathrm{~cm} / \mathrm{yr}$, over $2000 \mathrm{~km}$ can be assumed [Plank et al., 2000]. Assuming an average density of $2.9 \mathrm{~g} / \mathrm{cm}^{3}$ for the upper $500 \mathrm{~m}$ of oceanic crust, about $1.410^{4} \mathrm{~g} / \mathrm{yr}$ are recycled. From our calculations, the associated $\mathrm{K}$ fluxes are $3.810^{3} \mathrm{~g} / \mathrm{yr}$ using the core-derived proportions and $5.810^{3} \mathrm{~g} / \mathrm{yr}$ using the log-derived proportions. The $\mathrm{U}$ fluxes calculated in the same manner are respectively 4.7 $10^{-3} \mathrm{~g} / \mathrm{yr}$ and $5.410^{-3} \mathrm{~g} / \mathrm{yr}$. K and U fluxes recycled into the subduction zone could therefore be higher than previously estimated, up to $20-50 \%$ for $\mathrm{K}$ and $10-20 \%$ for $\mathrm{U}$. These results can also have strong implications for chemical fluxes between the altered oceanic crust and seawater and further work is needed to extend this approach and combine it to a composite sample approach to access more chemical elements as well as the isotope compositions.

\section{Conclusion}

[44] In this paper we present a new approach to estimate the average composition of a drilled section by integrating core data, gamma ray wire line logging data and geochemical data. At ODP Site $801 \mathrm{C}$ a detailed core-log integration study was performed [Barr et al., 2002], which allowed reconstruction of the complete basement stratigraphy. The FMS images together with other wire line logging data and images of the recovered cores were used to relocate the samples. We then calculated average $\mathrm{K}_{2} \mathrm{O}$ and $\mathrm{U}$ contents of each core using the core-derived and log-derived rock types proportions and we compared them to the logging data. This approach have allowed us to demonstrate that the gamma ray tool (HNGS) is well calibrated against chemical analyses and MSTNGR data and enable to accurately determine the $\mathrm{K}_{2} \mathrm{O}$ and $\mathrm{U}$ concentrations downhole. By using the wire line log-derived proportions we can account for the more strongly altered, $\mathrm{K}_{2} \mathrm{O}$ and U-rich material, which is preferentially lost during drilling. The calculations undertaken in this study indicate that logging data are reliable enough to be used as a proxy for the $\mathrm{K}_{2} \mathrm{O}$ and $\mathrm{U}$ concentrations of a borehole. We demonstrate that $\mathrm{K}$ and $\mathrm{U}$ fluxes are higher when log-derived proportions or gamma ray data are used instead of expanded core-derived proportions. The calculated fluxes are $20-50 \%$ higher for $\mathrm{K}$ and $10-20 \%$ higher for $\mathrm{U}$.

[45] Our results indicate that $\mathrm{K}_{2} \mathrm{O}$ concentrations and to a lesser extent $\mathrm{U}$ concentrations can be overestimated because inappropriate samples with extreme end-member compositions are often used. Composite samples should be prepared with extreme caution and this preparation integrated with wire line logging data to ensure that appropriate, representative samples of each rock type are combined in the correct, log-derived, proportions. In order to better constrain chemical fluxes between the oceanic crust and seawater as well as recycled into subduction zones, careful core-log-geochemical integration studies are essential. 


\section{Acknowledgments}

[46] Authors are grateful to K. Kelly for providing some of her unpublished data and D.A.H. Teagle for helpful comments on earlier version of the manuscript. Careful and detailed reviews by Katy Gillis, Jeff Alt, Terry Planck and John Ludden very much improved the manuscript and are greatly acknowledged. This research used data provided by the Ocean Drilling Program (ODP). The ODP is sponsored by the U.S. National Science Foundation (NSF) and participating countries under management of Joint Oceanographic Institutions (JOI), Inc. Funding for this research was provided by a grant from the Natural Environment Research Council (NERC, Grant GST/ 02/2728).

\section{References}

Alt, J. C., and D. A. H. Teagle, The uptake of carbon during alteration of oceanic crust, Geochim. Cosmochim. Acta, 63, 1527-1535, 1999.

Alt, J. C., D. A. H. Teagle, T. S. Brewer, W. C. Shanks III, and A. N. Halliday, Alteration and mineralizaion of an oceanic forearc and the ophiolite-ocean analogy, J. Geophys. Res., 103, 12,365-12,380, 1998.

Barr, S. R., S. Révillon, T. S. Brewer, P. K. Harvey, and J. Tarney, Determining the inputs to the Mariana Subduction Factory: Using core-log integration to reconstruct basement lithology at ODP Hole 801C, Geochem. Geophys. Geosyst., 3(11), doi:10.1029/2001GC000255, 2002.

Bartolini, A., and R. L. Larson, Pacific Microplate and the Pangea supercontinent in the Early to Middle Jurassic, Geology, 29, 735-738, 2001.

Borehole Research Group, ODP Logging manual: An electronic guide to ODP logging services, Lamont Doherty Earth Obs. of Columbia Univ., Palisades, N.Y., 2000. (Available at http://www.ldeo.columbia.edu/BRG/ODP/LOGGING/ MANUAL/index.html)

Brewer, T. S., et al., Ocean floor volcanism: Constraints from the integration of core and downhole logging measurments, in Core-Log Integration, edited by P. K. Harvey and M. A. Lovell, pp. 341-362, Geol. Soc. London Spec. Publ., London, 1998.

Brewer, T. S., P. K. Harvey, S. Haggas, P. Pezard, and D. Goldberg, Borehole images of the ocean crust: Case histories from the Ocean Drilling Program, in Borehole Imaging: Applications and Case Histories, edited by M. A. Lovell, G. Williamson, and P. K. Harvey, pp. 283-294, Geol. Soc. London Spec. Publ., London, 1999.

Castillo, P. R., P. A. Floyd, and C. France-Lanord, Isotope geochemistry of Leg 129 basalts: Implications for the origin of the widespread Cretaceous volcanic event in the Pacific, Proc. Ocean Drill. Program Sci. Results, 129, 405-414, 1992.

Elliot, T., T. Plank, A. Zindler, W. White, and B. Bourdon, Element transport from subducted slab to volcanic front at the Mariana Arc, J. Geophys. Res., 102, 14,991-15,019, 1997.
Farr, L. C., T. Plank, K. Kelley, and J. C. Alt, U mineral hosts and enrichment processes in altered oceanic crust, Eos Trans. $A G U$, 82(47), Fall Meeting Suppl., F1147, 2001.

Floyd, P. A., and P. R. Castillo, Geochemistry and petrogenesis of Jurassic ocean crust basalts, Site 801, Proc. Ocean Drill. Program Sci. Results, 129, 361-388, 1992.

Floyd, P. A., J. A. Winchester, and P. R. Castillo, Geochemistry and petrography of Cretaceous sills and lava flows, Sites 800 and 802, Proc. Ocean Drill. Program Sci. Results, 129, 345-360, 1992.

Fouch, M. J., and K. M. Fischer, Mantle anisotropy beneath northwest Pacific subduction zones, J. Geophys. Res., 101, 15,987-16,002, 1996.

Fryer, P., C. G. Wheat, and M. J. Mottl, Mariana blueschist mud volcanism: Implications for conditions within the subduction zone, Geology, 27, 103-106, 1999.

Haggerty, J. A., I. Premoli Silva, F. Rack, and M. K. McNutt, Proceedings of the Ocean Drilling Program, Scientific Results, vol. 144, Ocean Drill. Program, College Station, Tex., 1995.

Harvey, P. K., T. S. Brewer, M. A. Lovell, and S. A. Kerr, The estimation of modal mineralogy: A problem of accuracy in core-log calibration, in Core-Log Integration, edited by P. K. Harvey and M. A. Lovell, pp. 25-38, Geol. Soc. London Spec. Publ., London, 1998.

Ishikawa, T., and F. Tera, Two isotopically distinct fluid components involved in the Mariana Arc: Evidence from Nb/B ratios and $\mathrm{B}, \mathrm{Sr}, \mathrm{Nd}$, and $\mathrm{Pb}$ isotope systematics, Geology, 27, 83-86, 1999.

Lancelot, Y., et al., (Ed.), Proceedings of Ocean Drilling Program Initial Reports, vol. 129, Ocean Drilling Program, College Station, Tex., 1990.

Lovell, M. A., et al., Applications of FMS images in the Ocean Drilling Program: An overview, in The Geological Evolution of Ocean Basins: Results From the Ocean Drilling Program, edited by A. Cramp et al., pp. 287-303, Geol. Soc. London Spec. Publ., London, 1998.

Morris, J., et al., Summary Subduction Factory project, paper presented at the SubFac workshop, La Jolla, Calif., 1998.

Peate, D. W., and J. A. Pearce, Causes of spatial compositional variations in Mariana arc lavas: Trace element evidence, The Island Arc, 7, 479-495, 1998.

Plank, T., and C. H. Langmuir, The chemical composition of subducting sediment: Implications for the crust and mantle, Chem. Geol., 145, 325-394, 1998.

Plank, T., J. N. Ludden, and C. Escutia, ODP Leg 185 Shipboard Scientific Party, (Eds.), Proceedings of Ocean Drilling Program Initial Report, vol. 185, Ocean Drill. Program, College Station, Tex., 2000.

Plank, T., R. Stern, and J. Morris, The Subduction Factory Science Plan, MARGINS Office, Palisades, N.Y., 1998. (Available at http://www.soest.hawaii.edu/margins/SubFac. html).

Pringle, M. S., Radiometric ages of basaltic basement recovered at Sites 800, 801, and 802, Leg 129, western Pacific Ocean, in Proceedings of the Ocean Drilling Program, Scientific Results, edited by R. L. Larson, Y. Lancelot, A. Fisher, and E. L. Winterer, Ocean Drilling Program, 
Texas A\&M University, College Station, TX, pp. 389404, 1992.

Rider, M., The Geological Interpretation of Well Logs, Whittles Publishing, Caithness, 1996.

Shipboard Scientific Party, Site 801, in Proc. ODP Init. Repts., edited by S. Premoli Silva, J. Haggerty, and F. Rack, Ocean Drilling Program, College Station, TX, pp. 313-329, 1993.

Staudigel, H., G. R. Davies, R. S. Hart, K. M. Marchant, and B. M. Smith, Large scale isotopic Sr, Nd, O isotopic anatomy of altered oceanic crust: DSDP/ODP sites 417/418, Earth Planet. Sci. Lett., 130, 169-185, 1995.

Staudigel, H., T. Plank, W. White, and H. U. Schmincke, Geochemical fluxes during seafloor alteration and the basaltic upper oceanic crust: DSDP Sites 417 and 418, in Subduction Top to Bottom, Geophys. Monogr. Ser., vol. 96, edited by G. E. Bebout, et al., pp. 19-38, AGU, Washington, D. C., 1996.
Stern, R. J., et al., Enriched back-arc basin basalts from the northern Mariana Trough: Implications for the magmatic evolution of back-arc basins, Earth Planet. Sci. Lett., 100, 210-225, 1990.

Suyehiro, K., et al., Continental crust, crustal underplating, and low-Q upper mantle beneath an oceanic island arc, Science, 272, 390-392, 1996.

Tatsumi, Y., M. Murasaki, and S. Nodha, Across-arc variation of lava chemistry in the Izu-Bonin arc: Identification of subduction components, J. Volcanol. Geotherm. Res., 49, 179190, 1992.

Taylor, B., Rifting and the volcanic-tectonic evolution of the Izu-Bonin-Mariana arc, Proc. Ocean Drill. Program Sci. Results, 129, 627-651, 1992.

Van der Hilst, R., and T. Senon, Effect of relative plate motion on the deep structure and penetration depth of slabs below the Izu-Bonin and Mariana island arcs, Earth Planet. Sci. Lett., 120, 375-407, 1993. 